NOTE

1. This study was supported by a grant from the National Institute of Mental Health (MH-12120). We acknowledge the advice and assistance of Minnie B. Koresko. After August 1970 , reprints may be obtained from $\mathrm{E}$. Hearst, Department of Psychology, Indiana University, Bloomington, Ind. 47401.

\title{
Effects of methylphenidate on activity and reactions to novelty in rats
}

\author{
LESLEY J. DYNE and R. N. HUGHES, \\ University of Canterbury, Christchurch, \\ New Zealand
}

Rats injected with 4.0 or $8.0 \mathrm{mg} / \mathrm{kg}$ of methylphenidate prior to observation in a four-cell exploration box showed a significant preference for the less novel half of the apparatus and a reduction in eating and drinking compared with control animals injected with sterile water. The higher dosage also decreased freezing behavior but increased sniffing and the total number of cells entered. While confirming some previous findings, the results emphasized the need in drug studies for distinguishing between exploratory responses directed towards novel environmental stimuli and randomized, nondirected general activity.

Some authors (e.g., Berlyne, 1960; Hebb, 1955) suggest that exploratory behavior facilitates the maintenance of an optimum level of arousal by exposing the organism to a wider range of novel arousing stimuli, thereby raising arousal when it drops below this level. It accordingly follows that factors that raise arousal above the optimum level should produce a corresponding decrement in exploration. In other words, highly aroused animals should explore novel stimuli to a lesser extent than normal ones, thus enabling arousal to eventually drop to the optimum level again. Some investigators have observed this predicted relationship in rats performing under the influence of arousing stimulant drugs. For example, Stretch (1963) found that amphetamine reduced ambulation in a novel $Y$-maze, Leventhal \& Killackey (1968) reported that adrenalin chloride (a sympathetic stimulant) caused rats, stimulated with a flashing light and buzzer, to prefer the less novel of two compartments. Likewise, Berlyne, Koenig, \& Hirota (1966) found that methamphetamine increased the reward value of familiar rather than novel stimuli in a sensory reinforcement setting. However, contrary to the arousal hypothesis, Bindra \& Baran (1959) found that the stimulant drug, methylphenidate, increased sniffing behavior (a common index of exploration) and decreased lying. The present experiment was therefore designed to examine the effects of methylphenidate on exploration or preferences for novelty, and several measures of locomotor and general activity within the context of a single study. SUBJECTS AND APPARATUS

The Ss were 20 naive male Wistar rats approximately 100 days old. Each rat was tested in a transparent Perspex exploration box described in detail elsewhere (Hughes \& Swanberg, in press). The box comprised four $8 \times 8 \times 8$ in. cells, and could be divided into two mirror-image halves of two cells each by inserting two opaque Perspex slides into gaps in an opaque Perspex wall. Food and water was always available in both halves. Two such boxes were used, and they were illuminated by a circular 20-W fluorescent lamp 20 in. above each box. Approximately $60 \mathrm{~dB}$ of white noise provided an auditory masking background.

\section{PROCEDURE}

The Ss were divided into a control and

Table 1

Mean Scores of Each Group on Four Significant Measures

\begin{tabular}{lccc}
\hline & \multicolumn{3}{c}{ Group } \\
\cline { 2 - 4 } Measure & Control & $4.0 \mathrm{mg} / \mathrm{kg}$ & $8.0 \mathrm{mg} / \mathrm{kg}$ \\
\hline Entries & $23.6^{\mathrm{b}}$ & 44.8 & $75.6^{\mathrm{b}}$ \\
$\begin{array}{l}\text { Percent } \\
\text { Preference } \\
\text { for Novelty }\end{array}$ & $79.2 \mathrm{~b}$ & 45.0 & $31.0^{\mathrm{b}}$ \\
$\begin{array}{l}\text { Percent } \\
\text { Sniffing }\end{array}$ & 27.4 & 54.0 & $86.5 \mathrm{a}$ \\
$\begin{array}{l}\text { Percent } \\
\text { Freezing }\end{array}$ & 33.8 & 39.0 & $4.8 \mathrm{a}$ \\
\hline
\end{tabular}

a Group differs significantly $(p<.05)$ from the other two.

$b$ The only significant difference is between the two groups indicated. two experimental groups. The experimental groups received an intraperitoneal injection of either $4.0 \mathrm{mg} / \mathrm{kg}$ (six rats) or $8.0 \mathrm{mg} / \mathrm{kg}$ (six rats) of methylphenidate hydrochloride $130 \mathrm{~min}$ before testing, whereas the eight control animals were injected with $5 \mathrm{cc} / \mathrm{kg}$ of sterile water.

Each $S$ was confined to one-half of a box for $90 \mathrm{~min}$, with the slides separating the two halves in place. It was then removed, injected, and put back into the same half. After a further $30 \mathrm{~min}$, it was again removed while the slides were withdrawn, placed back in the same half and, $30 \mathrm{sec}$ later, continuously observed for $15 \mathrm{~min}$. The total number of cells entered (entries) was counted, and every 5 th sec it was noted whether the $S$ was in the previously inaccessible "novel" half or not (preference for novelty) and the sort of activity it was engaged in.

\section{RESULTS}

One of the $8.0-\mathrm{mg} / \mathrm{kg}$ rats was discarded because it spent the entire 15 -min observation period totally immobile Analyses of variance carried out on data ${ }^{2}$ from the remaining $S s$ revealed significant drug effects on four behavioral measures, i.e., entries, preference for novelty, sniffing (moving the snout through the air or over the floor and walls with vibrissae twitching), freezing (lying, crouching, or standing motionless). The significance of differences between individual groups was determined by Newman-Keuls tests. Mean scores on the four significant measures can be seen in Table 1.

Median tests were performed on measures in which adequate homogeneity of variance was not achieved, in spite of transformation. They showed that both drug groups ate or drank significantly less often than the control group, although they did not differ significantly from each other on either measure. Medians for both drug groups on both measures were 0 , whereas for the control group they were $27.1 \%$ and $7.1 \%$, respectively, on eating and drinking.

Sample $t$ tests showed that, contrary to the control group, both drug groups showed a significant preference for the less novel half of the apparatus.

The results indicated that methylphenidate reduced preference for the more novel half of the apparatus to the point where there was a significant preference for the less novel, or "familiar," half. At the higher dosage the drug also increased the number of cells entered and the time spent sniffing, but decreased the time spent freezing and, at both dosages, the time spent eating or drinking.

\section{DISCUSSION}

Bindra \& Baran (1959) found that 
$7.0 \mathrm{mg} / \mathrm{kg}$ of methylphenidate increased sniffing, decreased lying, and increased the frequency of activity change, which they took to be a measure of "instability" in the behavior of the rat. Similarly, in the present study $8.0 \mathrm{mg} / \mathrm{kg}$ was seen to generally increase overall activity (as shown by the sniffing and entries results) and decrease sitting or lying immobile (freezing). At this dosage it was often incidentally observed, although not recorded, that the rats seemed incapable of completing a specific act before engaging in some other activity. In other words, methylphenidate appeared to disorganize behavior or, to quote Bindra and Baran, to increase "instability."

As the drug also markedly decreased preference for the more novel half of the apparatus, and as reactivity towards novel stimuli is generally accepted as the most valid index of exploratory tendencies, it could be concluded that methylphenidate decreased exploratory behavior as well. It is therefore obvious that in assessing dng effects on exploration one must endeavor to distinguish between behavior directed specifically towards the more novel components of an environment (i.e., exploration) and randomized general activities characterized by a lack of consistent environmental orientation. Clearly, in the present study, methylphenidate inhibited the former while facilitating the latter. Such a reduction in novelty preference is consistent with results from other studies in which inverse relationships have been observed between high arousal (whether induced by chemical or environmental means) and reactivity to novel stimuli (e.g., Berlyne, Koenig, \& Hirota, 1966; Hayward \& Wachs, 1967; Leventhal \& Killackey, 1968).

\section{REFERENCES}

BERLYNE, D. E. Conflict, arousal and curiosity. New York: McGraw-Hill, 1960.

BERLYNE, D. E., KOENIG, J. D. V., \& HIROTA, T. Novelty, arousal and the reinforcement of diverse exploration in the rat.
Journal of Comparative \& Physiological Psychology, 1966, 62, 222-226.

BINDRA, D., \& BARAN, D. Effects of methylphenidate and chlorpromazine on certain components of general activity. Joumal of the Experimental Analysis of Behavior, 1959, 2, 343-350.

HAYWOOD, H. C., \& WACHS, T. D. Effects of arousing stimulation upon novelty preference in rats. British Journal of Psychology, 1967, $58,77-84$.

HEBB, D. O. Drives and the C.N.S. (conceptual nervous system). Psychological Review, 1955, 62, 243-254.

HUGHES, R. N., \& SWANBERG, K. M. Effects of food deprivation on exploration in deprivationally naive rats. Australian Journal of Psychology, in press.

LEVANTHAL, G. S., \& KILLACKEY, H. Adrenalin, stimulation and preference for novel stimuli. Journal of Comparative \& Physiological Psychology, 1968, 65, 152-155.

STRETCH, R. Effects of amphetamine and pento-barbitone on exploratory behaviour in rats. Nature, 1963, 199, 787-789. NOTES

1. The drug used is marketed by CIBA Laboratories as RITALIN.

2. To achieve homogeneity of variance, proportional data were transformed by the formula, angle $=$ arc sin $\sqrt{\text { percentage. }}$ 